\title{
PEMANFAATAN LAHAN UNTUK PENYERAPAN LUBANG RESAPAN BIOPORI DAN MEMBUAT TANAMAN HIDROPONIK DI PERUMAHAN GRAHA HARAPAN MUSTIKA JAYA BEKASI
}

\author{
Anton Robiansyah ${ }^{*}$ \\ Edward Zubir ${ }^{2}$ \\ Nirdukita Ratnawati ${ }^{3}$ \\ Sri Sukatmi ${ }^{4}$ \\ Sri Maulidia ${ }^{5}$ \\ Yasir Riady 6 \\ $1^{*}, 2,4,5,6$ Universitas Terbuka, Indonesia \\ ${ }^{3}$ Universitas Trisakti, Indonesia \\ anton.robiansyah@ecampus.ut.ac.id ${ }^{1^{*}}$ \\ edoz@ecampus.ut.ac.id ${ }^{2}$ \\ nirdukita.ratnawati@trisakti.ac.id ${ }^{3}$ \\ srisukatmi@ecampus.ut.ac.id ${ }^{4}$ \\ srimaulidia@ecampus.ut.ac.id ${ }^{5)}$ \\ vasir@ecampus.ut.ac.id ${ }^{6}$
}

Kata Kunci:
[Lubang
Resapan
Biopori,
Tanaman
Hidroponik]

Published by:

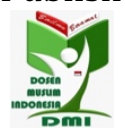

Copyright (C) 2022 The Author(s)

This article is licensed under CC BY 4.0 License

\begin{abstract}
Abstrak: Banjir merupakan musuh tahunan warga di tanah air salah satu wilayahnya yaitu Graha harapan Mustika Jaya Kota Bekasi, banjir terjadi karena drainase lingkungan yang buruk dan kurangya daerah resapan air. Banjir ini tidak hanya menjadi tanggungjawab pemerintah tetapi juga menjadi tanggungjawab setiap masyarakat. Tim Pengabdian kepada masyarakat (PKM) tergerak untuk ikut membantu program pemerintah melalui kegiatan sosialisasi dan pelatihan yang diberikan kepada masyarakat diperumahan Graha harapan Mustika Jaya Bekasi tetang bagimana cara mengatasi banjir dengan menggunakan teknik lubang resapan biopori dan pelatihan bagaimana membuat alat untuk tanaman hidroponik. Pelaksanaan PKM ini dihadiri oleh 27 orang peserta dengan semua yang hadir adalah ibu-ibu di perumahan Graha harapan Mustika jaya Bekasi. Kegiatan ini diawali dengan penjajakan dan koordinasi, kemudian dilanjutkan dengan pelaksanaan sosialisasi dan pelatihan, serta evaluasi terhadap peserta pelatihan. Hasil dari pengabdian kepada masyarakat ini berupa berbagi ilmu pengetahuan baru tentang manfaat lubang resapan biopori (LRB) untuk mengurangi terjadinya banjir dan praktik pelatihan pembuatan alat hidroponik untuk meningkatkan produktivitas warga terhadap kebutuhan pokok. Pembuatan LRB dapat berguna untuk menjaga lingkungan dari terjadinya banjir dan pembuatan alat hidroponik dapat membudidayakan tanaman hdirponik sehingga warga perumahan graha harapan tidak perlu membeli sayur kembali dan juga harapan lainnya adalah munculnya wirausaha baru di Kota Bekasi dalam pengembangan bisnis tanaman hidroponik.
\end{abstract}

(cc) $\mathrm{BY}$

https://dmi-journals.org/jai 


\section{Pendahuluan}

Banjir merupakan musuh tahunan warga di sejumlah daerah di tanah air. Pembukaan lahan, perataan tanah untuk pembangunan pemukiman dan prasarana lainnya mengakibatkan pemadatan tanah. Pada saat pembangunan sebagian permukaan lahan dipadatkan untuk bangunan dan prasarana jalan. Hal ini mengakibatkan sebagian besar air hujan tidak dapat meresap ke dalam tanah. Buruknya saluran pembuangan air (drainase) serta menurunnya daya serap tanah akibat pembangunan mengakibatkan banjir. Banjir adalah peristiwa yang terjadi ketika aliran air yang berlebihan merendam daratan (www.wikipedia.com). Banjir dapat berupa genangan pada lahan yang biasanya kering seperti pada lahan pertanian, permukiman, pusat kota. Banjir dapat juga terjadi karena debit/volume air yang mengalir pada suatu sungai atau saluran drainase melebihi atau diatas kapasitas pengalirannya.

Wilayah Jabodetabek diguyur hujan lebat tanggal 31 Desember 2019 sekitar pukul 17.00 WIB sampai 1 Januari 2020 sekitar pukul 11.00 WIB. Curah hujan yang mengguyur tercatat $377 \mathrm{~mm}$ per hari. BMKG menyebut curah hujan ini tertinggi sejak 1996. Akibatnya ada 169 titik banjir di seluruh wilayah Jabodetabek dan Banten, seperti disampaikan Kapusdatin dan Humas BNPB Agus Wibowo. Titik banjir terbanyak berada di Provinsi Jawa Barat 97 titik, DKI Jakarta 63 titik dan Banten 9 titik. Dari data tersebut dapat disimpulkan bahwa wilayah yang paling terdampak banjir adalah Kota Bekasi (53), Jakarta Selatan (39), Kabupaten Bekasi (32), dan Jakarta Timur (13) (CNN.Indonesia).

Daerah Bekasi tepatnya di Perumahan Graha Harapan ikut terkena dampak banjir. Banjir ini tidak hanya menjadi tanggungjawab pemerintah tetapi juga menjadi tanggungjawab setiap masyarakat, apa yang bisa dilakukan oleh masayarakat adalah dengan menjaga lingkungan, tidak membuang sampah sembarangan dan memanfaatkan sumberdaya alam dilingkungan sekitar dengan baik. Dalam rangka pemanfaatan sumber daya alam baik berupa tanah dan air perlu direncanakan dan dikelola secara tepat melalui suatu sistem pengelolaan Lubang Resapan Biopori (LRB). Menurut Insiyur Brata (2000) dosen Ilmu Tanah dan Sumber Daya Lahan Institut Pertanian Bogor, Jawa barat, menemukan satu metode teknologi yang sangat sederhana tetapi memiliki dampak yang sangat besar bagi lingkungan yaitu LRB. LRB adalah lubang-lubang tanah yang terbentuk akibat aktivitas organisme didalamnya, seperti cacing, perakaran tanah, rayap dan fauna tanah lainnya. Selain dapat meresapkan air dengan cepat, LRB ini juga dapat menjaga keteresediaan air tanah dikala musim kemarau tidak hanya sebagai pencegah banjir, penerapan biopori yang secara rutin akan menghasilkan pupuk kompos yang sangat bermanfaat bagi tanaman. Membuat LRB ini tidak memerlukan lahan yang luas tetapi LRB ini dapat dibuat dilingkungan sekitar perumahan-perumahan di kawasan Bekasi khususnya di Perumahan Graha Harapan.

Maka dari itu LRB akan menghasilkan pupuk kompos. Adanya pupuk kompos ini dapat mendorong masyarakat dan santri agar dapat bercocok tanam didekat lingkungan sekitar rumah mereka dan juga lingkungan pesantren yang dapat dimanfaatkan. Pemanfaatan lahan dilingukan sekitar rumah dan pesantren adalah dengan menanam tanaman hidroponik. Hidroponik adalah lahan budidaya pertanian tanpa menggunakan media tanah, sehingga hidroponik merupakan aktivitas pertanian yang dijalankan dengan menggunakan air sebagai medium untuk menggantikan tanah (Roidah, 2015). 
Sehingga sistem bercocok tanam secara hidroponik dapat memanfaatkan lahan yang sempit.

Pertanian dengan menggunakan sistem hidroponik memang tidak memerlukan lahan yang luas dalam pelaksanaannya, tetapi dalam bisnis pertanian hidroponik hanya layak dipertimbangkan mengingat dapat dilakukan di pekarangan rumah atap rumah maupun lahan lainnya. Kebutuhan pangan bagi manusia seperti sayuran dan buahbuahan semakin meningkat dengan seiring perkembangan jumlah penduduk, dengan adanya hidroponik ini masyarakat diharpakan dapat memenuhi kebutuahan akan sayuran dan tanaman hidroponik ini dapat menjadi bisnis baru yang bernilai ekonomis bagi masyakarat dilingkungan perumahan Graha Harapan.

\section{Metode Pelaksanaan}

Agar pelatihan pembuatan LRB dapat berhasil, tim PkM akan melakukan sosialisasi dan koordinasi dengan pihak berwenang setempat (RT, RW, Kelurahan, Kelompok/Mitra) sebelum penyuluhan dan pelatihan dilaksanakan. Selanjutnya, tim PkM mengajak pengurus RT, RW, ketua kelompok/mitra untuk membuat daftar peserta sosialisasi dan pelatihan penerapan Lubang Resapan Biopori di perumahan Graha Harapan Blok B Mustika Jaya Bekasi.

Pada saat acara pelatihan, pengurus RT, RW dan ketua kelompok mengundang para peserta untuk mengikuti pemaparan tentang pemahaman pentingnya menjaga lingkungan dan pembuatan LRB dengan baik. Sosialisasi dan pelatihan dilakukan secara bersama-sama oleh tim PkM kepada masyarakat, tetapi ketika memulai proses pembuatan secara langsung maka tim PkM akan membagi peserta menjadi beberapa kelompok, sehingga semua peserta dapat mempraktekkan cara membuat LRB secara langsung dengan didampingi beberapa mahasiswa. Tim PkM yang sudah ditunjuk akan memberikan tips/metode tentang pembuatan LRB dengan baik serta menyiapkan semua peralatan yang dibutuhkan.

Hasil dari pembuatan Biopori ini dapat menjadi pupuk kompos yang bermanfaat bagi kesuburan tanaman, jika memungkinkan pupuk kompos ini dapat digunakan untuk tanaman sehingga bernilai ekonomis dan masyarakat mendapatkan keuntungan tidak hanya dikonsumsi sendiri tetapi juga dapat menjadi sumber pendapatan.

\section{Hasil dan Pembahasan}

Pengabdian kepada masyarakat yang dilaksanakan dengan metode sosialisasi dan pelatihan kepada 27 orang anggota yang berada di perumahan Graha Harapan Mustika Jaya Bekasi. Sosialisasi dan pelatihan ini diharpakan dapat membantu warga sesaui dengan tujuan dari PKM yaitu memberikan edukasi kepada anggota dan masyarakat tentabg teknik/metode pembuatan dan pengelolaan biopri untuk pencegahan banjir serta mengajarkan dan melatih anggota dan masyarakat bagaimana teknik/metode pembuatan tanaman hidroponik. Pelaskanaan PKM ini dilakukan secara tatap muka kepada anggota PKM yang dihadiri sekitar 27 orang peserta, pelaksanaan ini dilaksanakan didalam masjid At-Taqwa di perumahan graha harapan Mustika Jaya Bekasi pada tanggal 17 November 2020.

Berkaitan dengan pengabdian kepada masyarakat yang dilakukan oleh tim, adapun pelaksanaan yang dilakukan antara lain: 
1. Penjajakan dilakukan pada bulan januari 2020 dan melakukan koordinasi untuk mengadakan kegiatan pengabdian kepada masyarakat yang akan dilakukan dengan Ketua RW 017 Perumahan Graha Harapan Bekasi.

2. Selanjutnya masih dibulan januari Ketua RW 017 menyetujui untuk diadakan pelaksanaan pengabdian kepada masyarakat di perumahan graha harapan dan penandatanganan kesediaan kerjasama mitra.

3. Bulan Maret-Agustus terjadi covid sehingga pelaksanaan pengabdian kepada masyarakat menjadi tertunda.

4. Awal bulan oktober tim pengabdian kepada masyarakat kembali menghubungi Ketua RW 017 perumahan graha harapan untuk mengkonfirmasi masyarakatnya apakah bersedia pengabdian kepada masyarakat dilanjutkan.

5. Beberapa hari kemudian tim pengabdian kepada masyrakat datang secara langsung kepada ketua RW 017 perumahan graha harapan mustika jaya Bekasi melakukan koordinasi persiapan pelaksanaan pengabdian kepada masyarakat, kapan waktu pelaksanaan pengabdian kepada masayrakat akan dilaksanakan.

6. Pelaksanaan pengabdian kepada masyarakat dilaksnakan pada hari selasa, 17 November 2020.

7. Pada saat pelaksanaan tim pengabdian kepada masyarakat melakukan sosialisai tentang manfaat dan cara membuat lubang resapan biopori menggunakan bor yang telah tim pengabdian kepada masyarakat siapkan.

8. Setelah sosialisasi tentang biopori tim pengabdian kepada masyarakat melakukan sosialisasi tentang tanaman hidroponik dan pelatihan secara langsung bagaimana pembuatan alat hidroponik serta bagaimana cara menanamnya.

9. Terakhir pemberian alat untuk tanaman hidroponik yang diwakili oleh 6 orang anggota setiap kelompok pengabdian kepada masyarakat untuk menerimanya dan diserahkan oleh tim pengabdian kepada masyarakat.

10. Monitoring dilakukan secara online dengan mereka mengirimkan bagaimana bibit yang akan ditanam.

Kegiatan pengabdian kepada masyarakat ini memiliki 2 kegiatan yaitu tentang pemanfaatan lahan untuk penyerapan Lubang Resapan Biopori Dan Membuat Tanaman Hidroponik Di Perumahan Graha Harapan Mustika Jaya Bekasi yang dilakukan secara tatap muka dengan metode sosialisasi dan pelatihan pembuatan tanaman hidroponik. Peserta yang hadir pada pelaksanaan PKM ini dihadiri oleh 27 peserta dan semuanya yang hadir adalah ibu-ibu. Anak-anak pesantren dan bapak-bapak tidak hadir karena anak-anak pesantren masih belum diperbolehkan masuk sekolah dan atas kesepatakan Ketua RW 017 dan warga maka yang hadir hanya para ibu-ibu, bapak-bapak belum diperbolehkan mengikuti PKM dikarenakan harus menerapakan kebijakan kurangi kerumunan dan social distance (jaga jarak). Sehingga peserta yang hadir adalah ibu-ibu saja, alasan anggota tim memilih ibu-ibu adalah ibu-ibu lebih banyak diam dirumah dan ibu-ibu memiliki potensi untuk belajar sehingga mampu mengaplikasikan apa yang akan disampaikan oleh tim PKM.

Kegiatan pertama adalah sosialisasi tentang lubang resapan biopori, sebelum masuk tentang lubang resapan biopori peserta diharpakan memahami apa yang menyebabkan terjadinya banjir. Mengutip pernyataan wakil Wali Kota Bekasi Tri Adhianto dalam blog harian aceh Indoensia tanggal 25 Februari 2020 menjelaskan, penyebab banjir di Bekasi, Jawa Barat, salah satunya karena banyaknya proyek nasional yang melintasi Kota Patriot ini. Penyebab terjadinya banjir lainnya yakni karena luapan 
Kali Bekasi dan aliran Kali Cakung dan Sunter. Untuk di Kali Bekasi dikarenakan sudah puluhan tahun belum dilakukan normalisasi. Luapan air terjadi karena kurangnya daerah resapan air yang ada di kota Bekasi dan masyarakat membuag sampah tidak pada tempatnya sehingga drainase menjadi tidak lancar.

Dengan adanya sosialiasi ini tim PKM dapat mengedukasi peserta abdimas agar dapat memahami apa yang dapat mengakibatkan banjir, sehingga mereka tidak membuang sampah sembarangan serta mencoba untuk memanfaatkan lahan sekitar untuk pembuatan lubang resapan biopori. Menurut Insiyur Brata(2000) dosen Ilmu Tanah dan Sumber Daya Lahan Institut Pertanian Bogor, Jawa barat, menemukan satu metode teknologi yang sangat sederhana tetapi memiliki dampak yang sangat besar bagi lingkungan yaitu LRB. LRB adalah lubang-lubang tanah yang terbentuk akibat aktivitas organisme didalamnya, seperti cacing, perakaran tanah, rayap dan fauna tanah lainnya. Selain dapat meresapkan air dengan cepat, LRB ini juga dapat menjaga keteresediaan air tanah dikala musim kemarau tidak hanya sebagai pencegah banjir, penerapan biopori yang secara rutin akan menghasilkan pupuk kompos yang sangat bermanfaat bagi tanaman.

Hal ini didukung oleh penelitian yang dilakukan oleh suwardi (2016) dengan judul pengaruh pemanfaatan biopori sebagai sumber resapan untuk menjaga ketersediaan air tanah di kecamatan sanrobone kabupaten takalar. Pengaruh pemanfaatan biopori terhadap ketersediaan air tanah dapat disimpulkan bahwa dengan membuat 4 lubang resapan biopori dan 1 lubang kontrol dengan menguji setiap jam pada setiap harinya menunjukkan bahwa volume air yang tersedia dibawah lubang resapan biopori mengalami peningkatan dengan ketinggian awal sebelum pengujian $0,65 \mathrm{~m}$ dan setelah pengujian $0,81 \mathrm{~m}$. Pengaruh meningkatnya volume air terlihat pada hari 1 dan 3 sedangkan pada hari 4 dan 5 sumur kontrol telah konstan terisi air. Membuat LRB ini tidak memerlukan lahan yang luas tetapi LRB ini bias dibuat dilingkungan sekitar perumahan-perumahan dikawasan Bekasi khususnya di Perumahan Graha Harapan. Adapun manfaat lubang resapan biopori adalah:

1. Mengatasi Banjir.

2. Tempat Pembuangan Sampah Organik

3. Penyubur Tanaman

4. Menambah Daya Resap Air di Lingkungan Rumah

5. Tanah yang Semakin Sehat Karena Aktivitas Biota Tanah

6. Meningkatkan Kawasan Hijau.

Berikut ini cara membuat lubang resapan biopori, dengan menggunakan bor tanah dan pipa sebagai penahan agar tanah tidak menutup lubang serta tempat untuk membuat pupuk kompos dengan memasukan dedaunan kedalamnya.

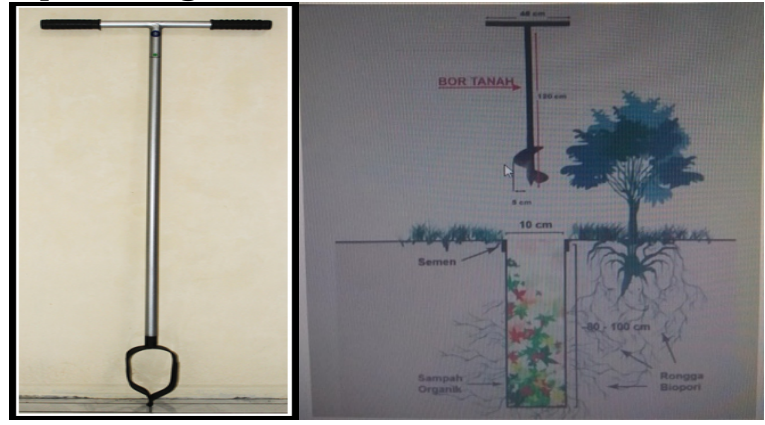

Gambar 1. Bor Tanah dan metode pembuatan lubang resapan biopori 
Kegiatan kedua adalah pelatihan membuat tanaman hidroponik. Hidroponik adalah lahan budidaya pertanian tanpa menggunakan media tanah, sehingga hidroponik merupakan aktivitas pertanian yang dijalankan dengan menggunakan air sebagai medium untuk menggantikan tanah (Roidah, 2015). Hidpronik ini dapat dilaksanakan tanpa memerlukan lahan yang luas tetapi bisa juga di pekarangan rumah, atap rumah maupun lahan lainnya karena hidroponik ini tidak memerlukan tanah. Adapun manfaat hidroponik secara umum sebagai berikut:

1. Untuk mendapatkan atau menghasilkan kualitas tanaman yang lebih baik.

2. Tanaman dapat terhidar dari hama.

3. Penggunaan pupuk menjadi lebih hemat.

4. Hemat tempat karena tidak memerlukan lahan tahan yang luas untuk menanam tanaman.

5. Tanaman dapat tumbuh dengan cepat.

6. Hemat tenaga dan waktu.

Sebelum masuk kepada praktik pelatihan pembuatan dan penamanam bibit hidroponik peserta PKM harus mengetahui bagaimana system hidroponik terlebih dahulu yaitu seperti pada gambar 2 berikut:

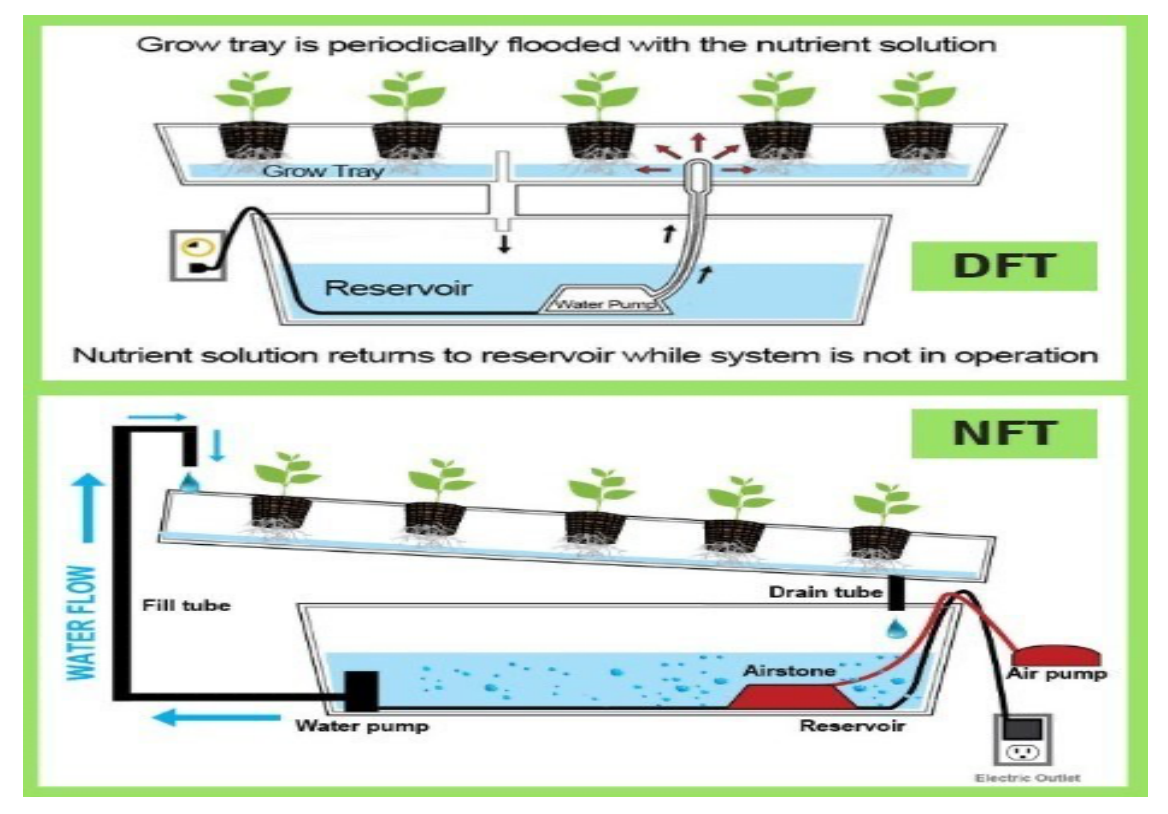

Gambar 2. Sistem Hidroponik

Pada gambar 2 ada daya listrik yang digunakan untuk menjalankan siklus air karena sumber tanaman hidroponik adalah air. Jadi masyarakat atau peserta PKM harus memahami bagaimana letak dan system sebuah alat hidroponik yang baik.

Setelah itu masuk pada proses selanjutnya yaitu tentang pembuatan alat hidroponik. Berikut ini merupakan alat dan proses pembuatan tanaman hidroponik menurut https://tipsbudidaya.com:

1. Persiapan Alat dan Bahan

Adapun bahan yang dibutuhkan adalah: Paralon berukuran 3 inch, Penutup paralon, Penyambung paralon, Lem paralon, Gergaji pemotong, Bor listrik, Wadah tanam dari botol/gelas plastik, selang, pompa aquarium, serta media \& benih tanam. 
2. Melubangi Paralon

Melubangi paralon adalah untuk mebuat wadah/tempat untuk meletakan nepot.

3. Pasang Netpot (atau gelas air mineral yang dilubangi)

Nepot merupakan wadah untuk meletakan bibit tanaman hidroponik

4. Pemindahan Bibit

Pemindahan bibit yang sudah siap untuk ditanam adalah yang sudah memiliki minimal 2 helai daun.

5. Pemberian Nutrisi Hidroponik

Pemberian nutrisi agar tanaman cepat tumbuh dan subur.

\section{Kesimpulan}

Pelaksanaan kegiatan Pengabdian kepada Masyarakat yaitu pemanfaatan lahan untuk penyerapan lubang resapan biopori dan membuat tanaman hidroponik di perumahan graha harapan mustika jaya bekasi telah berlangsung dengan sangat baik dan lancar sesuai dengan perencanaan kegiatan sebelumnnya. Kegiatan ini diawali dengan penjajakan dan koordinasi, kemudian dilanjutkan dengan pelaksanaan pelatihan, serta evaluasi terhadap peserta pelatihan. Hasil dari pengabdian masyarakat ini berupa ilmu pengetahuan dari sosialisasi tentang lubang resapan biopori untuk mengurangi terjadinya banjir dan praktik prlatihan pembuatan alat hidroponik. Tidak hanya pemberian materi tentang apa itu hidroponik, manfaat hidroponik, cara menanam dan merawatnya smapai dengan bagaimana cara membuat alat hidroponik dengan cara oraktik secara langsung.

Berdasarkan hasil daripada pelaksanaan PKM ini diharpakan bagi semua peserta PKM memahami tentang lubang resapan biopori, tanaman hidroponik dan cara pembuatan alat hidroponik, semoga PKM ini berguna bagi masyarakat kota Bekasi khusunya warga perumahan graha harapan Mustika Jaya Bekasi, untuk dapat menjaga lingkungan dan dapat membudidayakan tanaman hidroponik sehingga warga perumahan graha harapan tidak perlu membeli sayur kembali dan juga harapan lainnya adalah munculnya wirausaha baru dikota Bekasi dalam pengembangan bisnis tanaman hidroponik.

\section{Referensi}

Brata, K. R. 2008. Implementasi Sistem Peresapan Biopori Untuk Konservasi Sumber Daya Air. 9 Februari 2008. Jakarta.

Griandini.2017.JPMM. Penerapan Pembuatan Teknik Lubang Biopori Resapan Sebagai Upaya Pengendali Banjir Corry Yohana Universitas Negeri Jakarta.

Roidah, Ida Syamsu.2015. Pemanfaatan Lahan Dengan Menggunakan System Hidroponik.Jurnal.Univ Tulung Agung. 
Vol. 2. No. 1. Tahun 2022

Suwardi.(2016). Pengaruh Pemanfaatan Biopori Sebagai Sumber Resapan Untuk Menjaga Ketersediaan Air Tanah Di Kecamatan Sanrobone Kabupaten Takalar. Skripsi. Fak Sain Teknologi. UIN Allaudin Makassar.

https://tipsbudidaya.com/cara-membuat-hidroponik-paralon/diakses pada 25 januari $\underline{2020}$

www.wikipedia.com diakses pada 20 Januari 2020

https://www.cnnindonesia.com/teknologi/20200102205129-199-462007/sejarahbanjir-besar-jakarta-sejak-zaman-voc-hingga-2020 diakses pada 20 Januari 2020 